\title{
THE CRIMINAL LIABILITY OF CORPORATIONS AS CRIME PERPETRATORS
}

\author{
Evi Djuniarti \\ Badan Penelitian dan Pengembangan Hukum dan Hak Asasi Manusia, \\ Kementerian Hukum dan Hak Asasi Manusia Republik Indonesia, Jakarta \\ Corresponding emai: evi diuniarti@ vahoo.com \\ Paper received on: 18-05-2021 Revised on: 26-08-2021 Approved to be published on: 06-09-2021 \\ DOI: http://dx.doi.org/10.30641/dejure.2021.V21.311-320
}

\begin{abstract}
In terms of handling corporate crimes that culminate in "sentencing" or "giving punishment", corruption is referred to as a crime that has caused damage to life. However, this is not mentioned much in criminal law studies. In addition to sentencing, corporations that committed corruption must also return corporate assets to the state. This needs to be considered according to the philosophy of nature aequum est neminem cum alterius detrimento et injuria fieri locupletiorem. This philosophy means that no one can enrich themselves at the expense and suffering of others. This philosophy changes the source of this doctrinal principle, namely crime does not pay or crime shall not pay into an expression of resistance to crime perpetrators so that they cannot enjoy the results of the crime they committed. The statement of the problem in this paper is how is the philosophy of sentencing corporations that are perpetrators of corruption? This research used secondary data through literature study in the form of laws and descriptive analysis. The imposition of a criminal fine creates implications and juridical problems for corporations that committed corruption. The recommendation of this paper is to build an ideal model of sentencing corporation based on justice.
\end{abstract}

Keywords: Corporate liability; Corruptor; Criminal Law

\section{INTRODUCTION}

The discussion of corporations in Indonesian criminal law is currently still a priority in crimes. In corruption that occurred, corporations played an important role in several legal issues, such as forest fires, corruption, environmental damage, waste pollution and air pollution. In some of these crimes, there are still obstacles in terms of handling them.

The position of the purpose of sentencing is one of the important keys in the imposition of punishment itself. It can also be said that the imposition of a punishment must take into account the purpose of punishment. The importance of paying attention to the purpose of punishment seems to have also been noticed by the drafters of the new Criminal Code with the explicit formulation of the objectives of punishment in book-1 of the Draft Criminal Code year 2005 which states that:

- Sentencing has purpose to:

- Prevent crimes by enforcing legal norms for the protection of the community

- Socialize the convicts by conducting coaching so that they become good and useful people

- Resolve conflicts caused by crimes, restore balance and bring a sense of peace in socializing,

- Release the guilt of the convict,

- Sentencing is not intended to degrade human dignity.

The criminal dimension of corporate crime in Indonesia continues to grow in line with national and international economic developments. This dimension is patterned in forms such as defrauding stockholders, defrauding the public, defrauding the government, endangering the public welfare, endangering employees, and illegal intervention in the political process. ${ }^{l}$

Defrauding stockholders is intended not to actually report the profits obtained, thereby causing fraud to the shareholders. This dimension is closely related to the company's shareholders who were incorrectly informed about the amount

Suparman Marzuki, “Dimensi "Kejahatan Korporasi” dan Reaksi Sosial,” Jurnal Hukum 1, no. 2 (1994): 9-14. 
of profit earned from the company's business results. ${ }^{2}$

Defrauding the public is manifested in the form of conspiracy to determine unrepresentative prices and products. Another form is fraudulent service information (advertising) about a product from a particular company, such as Macho and Pil Kita advertisements that depict the strength of a man and so on. This is certainly very detrimental to society in its capacity as consumers. Meanwhile, defrauding the government is an act of fraud by a corporation aimed directly at the government. This action is committed to avoid the obligation to pay taxes in accordance with the actual corporate income or profits. Many large companies that are engaged in fields related to the lives of many people have more than one bookkeeping list. This is intended to trick the government so that they do not spend too much on paying taxes. ${ }^{3}$

Endangering the public welfare is a dimension of corporate crime that leads to endangering public welfare. It is like a corporation causing industrial pollution that harms the surrounding environment. Another dimension of corporate crime is endangering employees, namely they do not care about work safety. This kind of action is often carried out by several companies by exploiting the workforce without being accompanied by sufficient attention to their safety so that they experience accidents due to the company's production facilities and infrastructure that do not meet work safety standards. ${ }^{4}$

What is meant by illegal intervention in the public process is to make intervention that violates the law on the political process, especially in the context of public policy making by the government, such as donations of political funds to party campaigns in the general election process with the aim of achieving certain wishes or tendencies of the corporation concerned through the emergence of a government policy resulting from the election. ${ }^{5}$

Another dimension that may contain corporate crime is labor exploitation. This is

\footnotetext{
Hanafi, "Perkembangan Konsep Pertanggungjawaban Pidana dan Relevansinya Bagi Usaha Pembaharuan Hukum Pidana Nasional" (Universitas Indonesia, 1997), 5 .

Ibid., 6 .

Ibid , 6 .

Ibid., 7 .
}

because there is a tendency to develop unfair competition that leads to the development of monopolies, oligopolies, industrial concentration, market limitations, price fixing, misrepresenting products, ignoring legal provisions, and ignoring work safety. ${ }^{6}$

Niall E Coburn more broadly explains the dimensions related to corporate crime as follows: ${ }^{7}$

1. Embezzlement of company funds;

2. Fraud on the results of internal audits and violations of work compliance;

3. Violation of securities, including companies that do not apply the principle of openness to the public;

4. Bribery;

5. Sales of company assets involving insiders;

6. Market manipulation;

7. Corruption;

8. Avoiding the obligation to pay taxes;

9. Trading practices and market conduct;

10. Bankrupt company business;

11. Calculation of company profits that are disguised or falsified;

12. Dishonest company financial accounting;

13. Company operations related to political party transactions and director's obligations;

14. Regulations of a confidential nature;

15. Food standards;

16. Highway and train standards;

17. Economic crimes against and by workers;

18. Discriminatory practices at work and in the workplace;

19. Violation of environmental regulations;

20. Occupational health and safety.

Regarding victims of corporate crime, the victims caused by these crimes are generally not individual victims, but group victims. Corporate crimes often cause abstract victims because they are numerous and difficult to identify, and the problem is very complex. Etty Utju R.K, citing Muladi's opinion, identified victims of corporate crime as follows: ${ }^{8}$

\footnotetext{
6 Marzuki, “Dimensi "Kejahatan Korporasi” dan Reaksi Sosial," 11-12.

7 Niall E Coburn, "Corporate Investigations," Journal of Financial Crime 13, no. 3 (2006): 350-351.

8 Etty Utju R. Koesoemahatmadja, Hukum Korporasi
} 
1. Competitors as a result of industrial espionage crimes that violate intellectual property rights, unfair competition, monopolistic practices, and others;

2. The state as a result of corporate crimes, such as false information about government institutions, corruption, economic crimes, subversion crimes, and others;

3. Employees as a result of corporate crimes in the form of an unhealthy and unsafe work environment, restrictions on the right to form labor organizations, non-fulfilment of minimum wages, and others;

4. Consumers as a result of misleading advertisements, creating toxic and dangerous products, and others;

5. The public as a result of environmental pollution and destruction, embezzlement, tax evasion and others;

6. Shareholders/investors as a result of accounting fraud and forgery, and others.

If the classification of victims of corporate crime above is connected to the classification of victims of crime proposed by Sellin and Wolfgang, there are two important notes that need to be conveyed. First, the groups of victims of crime points 2, 3 and 4 are all included in the classification of victims of corporate crime. Meanwhile, point 1 , namely primary victimization, is not included in it. This is because generally the victims of corporate crime are not individuals. Second, the classification of victims of crime by Sellin and Wolfgang turned out to contain weaknesses because they did not include the state as part of the victims of crime.

Theoretically, as stated by Sam Park and Jong Song, there are three basic references that can be used to determine that a corporation is responsible for illegal acts committed by its management. ${ }^{9}$

1. A corporation is only responsible for crimes committed by its management if the actions are still within the scope and nature of their work in the corporation. The scope of the management's work is interpreted broadly.

Penegakan Hukum terhadap Pelaku Economic Crimes dan Perlindungan Abuse of Power (Jakarta: Ghalia, 2011), 6.

9 Sam Park dan John Song, “Corporate Criminal Liability,"' American Criminal Law Review 50, no. 4 (2013): 732-740.
One opinion states that the corporation is criminally responsible for crimes committed by the management as long as the management at the time of committing the crime is still within the scope of their work. The requirement that the management must act within the scope of their work is declared proven if the management has real authority or is deemed to have real authority to do so. What is meant by real authority here is that the corporation intentionally grants authority to the management to take an action on behalf of the corporation, while what is meant by being deemed to have real authority is if a third party believes that the management actually has the authority to take an action on behalf of the corporation. The verification of these two things depends on each legal system adopted by a country and the way court decisions interpret them.

2. The corporation is not criminally responsible for crimes committed by its management, unless the crime is intended to benefit the corporation. The factual benefits of a corporation over a crime committed by its management do not need to be real, but it is sufficient with the fact that the management deliberately gives these benefits to the corporation. The important thing that needs to be found and proven by the court is that from the outset the management has aimed (intentionally) to benefit the corporation. In addition, the corporation is not responsible for the crimes of the management if they violate the corporate policy, and the corporation does not benefit at all from the actions of the management. The corporation is also not responsible when the actions of the management clearly violate the principle of fiduciary duty.

3. To declare that a corporation is responsible for the crimes committed by its management, the court is obliged to delegate the intention of the management to the corporation. There are many ways that the court can take, including through the application of the concept of conspiracy, liability after mergers or dissolutions, misprision of felony, the willful blindness doctrine, and the collective knowledge doctrine. ${ }^{10}$

1o Park dan Song, “'Corporate Criminal Liability.” 
The determination of the guilt of a corporation that is proven to have committed a crime is basically closely related to the stages of recognizing a corporation as a subject of criminal law that can commit a prohibited act, namely; a) a corporation's management that commits a crime, only the management is responsible; b) a corporation that commits a crime, but the responsibility is imposed only on the management; and c) a corporation that commits a crime, and it is the corporation that is criminally responsible.

Since corporations cannot commit crimes without going through the intermediary of their management, both based on the theory of functional actors and identification theory, the determination of corporation guilt is to see whether the management, acting for and on behalf of the corporation, has guilt. If the answer is yes, then the corporation is found guilty of the crime it has committed. And vice versa. Mardjono Reksodiputro states that the guilt that is in the management of the corporation is transferred or becomes the guilt of the corporation itself. ${ }^{11}$

The theoretical framework for determining corporate guilt proposed by Mardjono can be understood if it is connected to the second stage of recognizing corporations as criminal law subjects, namely a corporation commits a crime, but the responsibility is imposed only on the management. Therefore, it is not surprising that the guilt of the management automatically becomes the guilt of the corporation. This step is taken because guilt is always directed against human law subjects, so it is necessary to find another basis for holding corporations accountable in criminal law. If in the end they think that corporations can be held accountable under criminal law, that too is done by 'humanizing' them. One way is to relate the characteristics or nature of human law subjects who are part of the corporation to the corporation itself. $^{12}$

In more detail, Chairul Huda states that the basis for determining the guilt of a corporation

\footnotetext{
" Mardjono Reksodiputro, "Kemajuan Ekonomi dan Kejahatan,” in Kumpulan Karangan (Jakarta: Universitas Indonesia, 1994), 107.

${ }_{12}$ Chairul Huda, "Asas Tiada Pidana Tanpa Kesalahan" Pelatihan Asas-asas Hukum Pidana dan Kriminologi serta Perkembangannya Dewasa Ini” (MAHUPIKI) bekerja sama dengan Fakultas Hukum UGM (Yogyakarta, 2014), 18.
}

is that the corporation's social functions are not properly fulfilled. ${ }^{13}$ In terms of society, corporations have not carried out their functions properly. An indicator of guilt of corporations is how corporations carry out their social functions. These social functions include those that do not work well, but are not limited to preventing crimes. Thus, the law expects corporations to carry out their social functions properly so as to avoid crimes. In other words, while it is possible for corporations to "be able to do other things" besides committing crimes, these expectations should be reflected as far as possible in their policies and the way they operate. The assessment of the existence of guilt is determined by how the corporation fulfils its social function so that it "can be reproached" when a crime occurs because of it. ${ }^{14}$ In the literature, the terms of guilt in corporations are called the terms of power (machtsvereiste). Muladi says the following. ${ }^{15}$

The terms of power include: the authority to regulate/control and/or command the party which in fact commits the prohibited act; capable of exercising their authority and basically capable of making decisions on the matter concerned; and capable to pursue policies or security measures in order to prevent prohibited acts from being committed. Based on the explanation above, it is deemed important to conduct research with the statement of the problem: how is the philosophy of sentencing corporations which commit corruption?

\section{RESEARCH METHOD}

Based on the type and form, the data needed in this research is secondary data obtained through literature study in the form of law and descriptive analysis, namely analyzing the laws and regulations. Secondary data is data obtained from a source that has been collected by other parties. In this case, the researcher conducted a search for library data consisting of:

a. Primary legal materials. To find out the juridical study, the researcher used the laws and regulations;

13 Ibid.

14 Ibid., 85-86.

${ }_{15}$ Muladi, "Demokratisasi, Hak Asasi Manusia dan Reformasi HURUM di Indonesia," The Habibie Center (The Habibie Center, 2002), 160-161. 
b. Secondary legal materials. In writing this paper, the researcher also used various scientific books, lecture materials and existing articles.

c. Tertiary legal materials. The tertiary legal materials that the researcher used include a legal dictionary and a complete Indonesian dictionary.

The data of this research was analyzed qualitatively. This means that library data, documents and literature were analyzed in depth and comprehensively. The use of qualitative analysis method is based on considerations, namely, first, the data being analyzed varies and have different basic characteristics from one data to another. Second, the basic nature of the data analyzed is comprehensive as a whole. It is characterized by the diversity of the data and it requires in-depth information.

\section{DISCUSSION AND ANALYSIS}

The 1945 Constitution of the Indonesian people is the product of the collective agreement of the entire Indonesian people through the MPR RI (People's Consultative Assembly) institutions (DPR and DPD), which is referred to as social contact. Meanwhile, the law is only a political contract representing the majority of the people and does not reflect the entire Indonesian people. This is because there are some Indonesian people who voted for a party, but the party did not qualify for the DPR RI (the House of Representatives). Pancasila is not one of the other pillars of the nation. However, Pancasila is the basis and source of all legal sources. Therefore, Pancasila contains universal values that we will continue to organize so that it becomes an umbrella for Indonesian people. ${ }^{16}$

The current paradigm of sentencing corporations which committed corruption in Indonesia has philosophical, sociological and juridical bases. The philosophical basis will realize justice (gerechtigheid), the sociological

16 Tim Humas DPD,"Prof. Dr. Jimly Asshiddiqie: Universalitas Pancasila Harus Terus Kita Tata Agar Menjadi Payung Bagi Seluruh Rakyat Indonesia," DPD RI DKI Jakarta, last modified 2021, diakses September 3, 2021, https://jakarta.dpd.go.id/index.php/public/ news/detail/prof.-dr.-jimly-asshiddiqie-universalitaspancasila-harus-terus-kita-tata-agar-menjadipayung-bagi-seluruh-rakyat-indonesia. basis realizes benefit (zweckmassigkeit) and the juridical basis realizes the dimension of legal certainty (recht zekerheids). The synergy of the three bases will give birth to the dimensions of moral justice, social justice and legal justice in the future criminal law political framework. These aspects and dimensions are mutatis mutandis in line with Romli Atmasasmita's thoughts on 21st century criminal law politics which is a series of processions for the establishment of criminal law originating from the results of social, economic, and political evaluations that develop in society with the aim of creating order, certainty, justice, and benefit which are measurable and accurate. ${ }^{17}$

The Indonesian Constitution as stated in the Fourth Paragraph of the 1945 Constitution of the Republic of Indonesia states that "therefore in order to establish an Indonesian state government that protects the entire Indonesian nation and the entire homeland of Indonesia and to promote public welfare, educate the nation's life, and participate in carrying out world order based on independence, eternal peace and social justice, then the independence of the Indonesian nationality is drawn up in a Constitution of the State of Indonesia, which is formed in a state structure of the Republic of Indonesia which is sovereign by the people...". The provisions of the Fourth Paragraph of the 1945 Constitution of the Republic of Indonesia regulate, give birth and develop two philosophical bases in the context of sentencing corporations as perpetrators of corruption.

First, the philosophical basis means that the founding fathers wanted Indonesia to be established as a rule of law. In the amendment of the 1945 Constitution of the Republic of Indonesia, the conception of the Indonesian Rule of Law is regulated in the provisions of Article 1 paragraph (3) of the third amendment of the 1945 Constitution of the Republic of Indonesia, which reads, "The State of Indonesia is a rule of law". This provision is derived from and adopted from the explanation of the 1945 Constitution before the amendment. In connection with this formulation, Moh. Mahfud MD explains that: ${ }^{18}$

17 Romli Atmasasmita, Analisis Ekonomi Mikro tentang Hukum Pidana Indonesia (Jakarta: Kencana Prenada Media Group, 2016), 193-194.

18 Mahfud MD, "Ceramah Kunci Ketua Mahkamah Konstitusi Republik Indonesia,” in Konferensi dan 
The conception of a rule of law that was previously thought to adhere to the conception of rechtsstaat was neutralized to become a rule of law only, without the label of rechtsstaat. Thus, the conception of the rule of law adopted by the 1945 Constitution of the Republic of Indonesia was obtained from both the rechtsstaat and the rule of law. Even other legal systems that are integrated (integrative) and whose implementation is adapted to the demands of development. The conception of the Indonesian rule of law accepts the principle of legal certainty which is the main thing in the conception of rechtsstaat as well as accepts the principle of a sense of justice which is a ritual of religious law. Written law and all of its procedural provisions (rechsstaat) are accepted, but must be placed in the context of upholding justice (rule of law). Written provisions that impede justice can be left out. This is confirmed in the provisions of Article 24 paragraph (1) of the 1945 Constitution of the Republic of Indonesia which states that the function of judicial power is to uphold law and justice, Article 28D paragraph (2) of the 1945 Constitution of the Republic of Indonesia concerning the right to obtain legal certainty and Article $28 \mathrm{H}$ paragraph (2) of the 1945 Constitution of the Republic of Indonesia which states that the law must be established based on justice and benefit.

In essence, the theory of the rule of law is philosophically created based on the spirit of promoting a legal system that guarantees justice, certainty, and the benefit of law for the protection of people's rights. The Indonesian state adopted the theory of the rule of law not in a formal sense, but in a material sense which is also termed a welfare state. ${ }^{19}$

The context of the material rule of law is the definition of a rule of law in a broad sense which is commonly referred to as a modern rule of law (modern rechtsstaat). In a material rule of law, the scope of the government's duties is not only to implement the provisions of the law, but also to participate in making laws or various other implementing regulations. The state does not only serve and function as a night watchman (nachtwakersstaat), but is also obliged to be

Dialog Negara Hukum: Negara Hukum Indonesia Ke Mana akan Melangkah (Jakarta, 2012), 62-63.

19 E. Utrecht, Pengantar Hukum Administrasi Negara Indonesia (Bandung: FHPM, 1960), 21-22. actively involved in various fields of the society's life in order to achieve the goals of the state.

In this context, the state must develop welfare so as to give birth to the concept of a welfare state. In a welfare state, it is known that the government has an obligation to carry out bestuurszorg or public service, namely the implementation of the public interest. The government is given broad authority to break away from the shackles of rigid formal law so that it can carry out its activities freely. The granting of broad authority is known as the freis ermessen doctrine or pouvoir discretionare. In simple terms, it can be formulated as "the independence of the government to be able to act on its own initiative in solving social problems". The freis ermessen doctrine can also be formulated as a legal authority for the government to intervene in social activities in order to carry out the tasks of organizing public welfare.

Regarding this matter, the government is obliged to synergize law enforcement efforts by realizing public welfare so that the handling of crimes must be carried out using an approach that is fair to the society through returning assets and instruments of crimes to the state for the benefit of public welfare.

Second, the Fourth Paragraph of the 1945 Constitution of the Republic of Indonesia establishes, regulates, and develops the dimensions of the state's role in carrying out its function for the welfare of the people and protecting the Indonesian nation. The sentencing of corporations which committed corruption from the perspective of philosophical basis prevents the potential to hinder the efforts of the Indonesian state to protect the entire Indonesian nation, both from internal and external threats. Crimes committed by corporations related to corruption, money laundering, the environment and so on are a serious threat to the resilience of the state and nation. Based on the correlation of the fourth paragraph of the 1945 Constitution of the Republic of Indonesia with corporate crimes, crimes committed by corporations cause widespread impacts, both direct and indirect. The sentencing of corporations is expected to advance public welfare and educate the nation's life. In addition, the impact of corporate crimes is greater than that of individuals. Then, the characteristics of corporate crime are manifested in the panorama of white-collar crime, transnational organized crime 
and business crime that cross cross-jurisdictional crimes so that the sentencing of corporations is also carried out in order to carry out the mandate of the state's goals which is in line with the 2nd and 5th Principles of Pancasila. Strictly speaking, corporate crime has the potential to hinder the implementation of the 5th Principle of Pancasila, namely to create and realize it must be in harmony with the 2nd Principle of Pancasila, namely the embodiment of a Just and Civilized Humanity.

The sociological basis for the sentencing of corporations which committed corruption is an objective description that the regulation was established with roots in the socio-community itself as an inner order in order to meet the needs of the society in various aspects. Therefore, the sociological basis actually illustrates the existence of empirical facts regarding the development of problems and needs of society and the state. The development of corruption practices in Indonesia with the paradigm as extraordinary crime, transnational organized crime, primum remedium and the most serious crime has taken root in all layers of the bureaucracy, so that the laissez-faire of corporations as perpetrators of corruption will result in enormous losses to the state's finance and economy. This will eventually disrupt the basic joints of the state's economic life.

The logical consequence of the progress of human civilization in various fields of life not only has a positive impact on improving the quality of life, but also has a negative impact with the development of various forms of crime, especially crimes that aim to gain economic benefits or better known as crimes committed by corporations with economic motive such as corruption which is part of the special criminal law (ius singulare, ius speciale or het bijzonder strafrecht).

The practice of crimes with economic motive in Indonesia such as corruption committed by corporations is now increasingly complex because it involves transnational or cross-country corporate actors. The development of corruption practices in Indonesia that have taken root and spread to all levels of the bureaucracy has resulted in enormous losses to the state's finance and economy. The main objective of the perpetrators of corruption by corporations and other crimes with economic motive is to obtain and enjoy the assets resulting from the crime.
If the sociological basis of the sentencing of corporations is examined from the perspective of the provisions of Law Number 31 Year 1999 in conjunction with Law Number 20 Year 2001, the public aspirations to eradicate corruption and other forms of irregularities committed by corporations are getting higher. On the one hand, in reality, there are acts of corruption committed by corporations that have caused enormous state losses, resulting in crises in various fields. On the other hand, corporations that committed corruption gain and enjoy the results of their crimes. Therefore, efforts to prevent, eradicate corruption, and create legal instruments capable of seizing all corporate assets from corruption need to be further enhanced and intensified while still upholding human rights and the interests of the society.

In addition, a legal instrument was made that regulates the formulation of modern corporate criminal liability which does not only refer to the principle of guilt (mens rea or guilty mind) as adopted by countries that adhere to the common law system with the starting point of the principle "an act does non facit reum nisi mens sit rea" (Latin), "geen straf zonder schuld" (Dutch), "keine strafe ohne schuld" (Germany). In certain cases, there should be a shift in the principle of "no crime without guilt" which turns into the principle of sentencing "without the need to consider the existence of guilt" and also known as the principle of "replacing guilt committed by others". It means that firmly and concretely the principle of no crime without guilt remains one of the main principles in criminal law. However, in certain cases, it is possible to apply the principle of strict liability and the principle of vicarious liability. In terms of strict liability, the perpetrator of a crime can be punished only because the elements of the crime of the perpetrator have been fulfilled. As for vicarious liability, a person's criminal liability is extended to the actions of his subordinates who do work or acts for him or within the limits of his orders.

In the context of the juridical basis for sentencing corporations, the perpetrators of corruption have been regulated in various regulations outside the Criminal Code. In the provisions of Article 59 of the Criminal Code, (ius constitutum/ius operaturn) it adheres to the principle of "societas delinquere non potest" or "universitas delinquere non potest", as stated by 
Pope Innocent IV, legal entities cannot commit crimes. This dimension is a reaction to the practice of absolute power before the French Revolution where it is possible to take collective responsibility for one's guilt. With the background of this principle, corporations cannot be punished because corporations do not have a heart and are not in the form of a human body so that they are impossible and unable to do wrong.

In the official explanation (memorie van toelichting) of the provisions of Article 59 of the Criminal Code, it is stated that a crime can only be realized by humans and the word about legal entities does not apply in criminal law. Therefore, the perpetrators of crimes who can be accounted for are only humans/people (natuurlijke persoon) because corporations cannot do anything, except by their management. This is as the Latin adage reads, "corporatio non dicitur aliquid facere nisi id sit collegialiter deliberari, etiamsi major pars id faciat". In 1918, the old Dutch Criminal Code was applied in the Dutch East Indies (the name of Indonesia at that time). ${ }^{20}$ The Dutch East Indies Criminal Code was used as the Indonesian Criminal Code $^{21}$ and is still valid today. That is why the Indonesian Criminal Code still considers that only humans can be the subject of criminal law. ${ }^{22}$ The formulation of Article 59 of the Indonesian Criminal Code is exactly the same as the formulation of Article 51 of the old Dutch Criminal Code. The provisions that apply in the Netherlands, Article 51 has been amended so that now in the Netherlands corporations have become the subject of criminal law. However, in Indonesia, the similar article still exists. Article 59 of the Indonesian Criminal Code remains so that

2o Nama asli KUHP adalah Wetboek van Strafrecht voor Nederlandsch Indie yang diberlakukan di Indonesia pertama kali dengan Koninklijk Besluit (Titah Raja) No. 33 pada 15 Oktober 1915. Hal ini mulai berlaku sejak 1 Januari 1918. Catatan ini mengingatkan KUHP yang berlaku pada saat ini telah lewat dari seabad umurnya. KUHP Hindia-Belanda adalah turunan dari KUHP Belanda lama (tahun 1886). Yang diberlakukan di Hindia-Belanda dengan asas konkordansi (penyesuaian).

${ }_{21}$ Pada masa pasca kemerdekaan, tepatnya pada 1946, Wetboek van Strafrecht Netherlands Indie, disahkan sebagai KUHP Indonesia.

22 Ketentuan ini ada karena KUHP Belanda lama dan KUHP Indonesia menganut asas universitas delinquere non potest, artinya: korporasi tidak dapat melakukan tindak pidana. the Indonesian Criminal Code does not consider corporations as a subject of criminal law. ${ }^{23}$

\section{CONCLUSION}

Criminal Procedure Law Code does not regulate the application and execution of corporate crimes. There is no formal criminal law that regulates law enforcement against corporate crimes, other than those regulated by the relevant laws. As in the law on the Eradication of Corruption, formal law to eradicate corporate crimes is contained in the provisions of Article 20. However, the existing formal law is still deemed insufficient and has not regulated the settlement of difficulties in prosecuting criminal corporations, including in corruption cases by corporations. To overcome this, the Supreme Court has issued the Supreme Court Regulation No. 13 Year 2016 concerning Procedures for Handling Crimes by Corporations, which has filled the absence of formal law.

In corporate crime, what is always debated is whether corporations can have guilt. To determine corporate guilt, there are several doctrines/ models. In Law No. 31 Year 1999 in conjunction with Law No. 20 Year 2001, the regulation of corporate guilt adheres to the doctrine/model of vicarious responsibility, namely that corruption is accountable to a corporation if it is committed by people, either based on work relationships or based on other relationships, acting within the corporate environment, either individually or jointly.

\section{SUGGESTION}

Seriousness and mutual understanding are needed among law enforcement officers regarding the application and execution of corporate crimes. It is also necessary to increase the expertise and abilityoflawenforcementofficersinhandlingcases of corporate crimes, including cases of corruption by corporations. If they fail to handle corporate crimes (which are clearly more complicated, more structured, and more systematic than ordinary crimes), then the initiative of eradicating corporate crimes (including eradicating corruption

\footnotetext{
23 Pasal 59 KUHP Indonesia sebenarnya memuat alasan penghapus pidana untuk pengurus yang tidak terlibat dalam tindak pidana. Namun, rumusan pasal ini memicu pertanyaan apakah korporasi dapat menjadi subjek hukum pidana.
} 
by corporations) will become stale. Although, the idea of eradication has passed more than 60 years with the intention of eradicating corruption which has been confirmed almost half a century ago (if calculated since the birth of Law No. 3 Year 1971).

Corporate crime in Indonesia is still not regulated in the Criminal Code, but the formulation that corporations can commit crimes has been spread in various laws outside the Criminal Code, including the Law on Corruption Eradication. Its formulation is not supported by sufficient formal law, but the absence has been filled with the Supreme Court Regulation No. 13 Year 2016 concerning Procedures for Handling Crimes by Corporations. However, the Supreme Court Regulation is not at the level of a law, so it would be awkward if the formulation of corporate crimes regulated in the law is supported by formal law regulated in regulations that are hierarchically under the law. It would be nice if the Supreme Court Regulation was immediately upgraded to become a law or adopted into the Draft Criminal Procedure Law Code and put into effect immediately.

\section{ACKNOWLEDGMENT}

The researcher would like to express gratitude to all colleagues who provided input and thought assistance so that the writing of this scientific paper can be completed properly, including to Ahyar Arigayo as the coordinator of Legal Researchers at Balitbangkumham, Syprianus Aristeus for suggestions on writing techniques and Muhaimin for suggestions on improving the substance of the writing and the use of Mendeley tools in the writing of this scientific paper.

\section{BIBLIOGRAPHY}

Tim Humas DPD, "Prof. Dr. Jimly Asshiddiqie: Universalitas Pancasila Harus Terus Kita Tata Agar Menjadi Payung Bagi Seluruh Rakyat Indonesia." DPD RI DKI Jakarta. Last modified 2021. Diakses September 3, 2021. https://jakarta.dpd.go.id/index.php/public/ news/detail/prof.-dr.-jimly-asshiddiqieuniversalitas-pancasila-harus-terus-kita-tataagar-menjadi-payung-bagi-seluruh-rakyatindonesia.

Atmasasmita, Romli. Analisis Ekonomi Mikro tentang Hukum Pidana Indonesia. Jakarta: Kencana Prenada Media Group, 2016.
Coburn, Niall E. "Corporate Investigations." Journal of Financial Crime 13, no. 3 (2006): 348-368.

Hanafi. "Perkembangan Konsep Relevansinya Bagi Usaha Pembaharuan Hukum Pidana Nasional." Universitas Indonesia, 1997.

Huda, Chairul. "Asas Tiada Pidana Tanpa Kesalahan" Pelatihan Asasasas Hukum Pidana dan Kriminologi serta Perkembangannya Dewasa Ini" (MAHUPIKI) bekerja sama dengan Fakultas Hukum UGM. Yogyakarta, 2014.

Koesoemahatmadja, Etty Utju R. Hukum Korporasi Penegakan Hukum terhadap Pelaku Economic Crimes dan Perlindungan Abuse of Power. Jakarta: Ghalia, 2011.

Marzuki, Suparman. "'Dimensi "Kejahatan Korporasi” dan Reaksi Sosial."' Jurnal Hukum 1, no. 2 (1994): 9-14.

MD, Mahfud. "Ceramah Kunci Ketua Mahkamah Konstitusi Republik Indonesia." In Konferensi dan Dialog Negara Hukum: Negara Hukum Indonesia Ke Mana akan Melangkah, 62-63. Jakarta, 2012.

Muladi. "Demokratisasi, Hak Asasi Manusia dan Reformasi HURUM di Indonesia." The Habibie Center. The Habibie Center, 2002.

Park, Sam, dan John Song. "“Corporate Criminal Liability." American Criminal Law Review 50, no. 4 (2013): 729-764.

Reksodiputro, Mardjono. "Kemajuan Ekonomi dan Kejahatan." In Kumpulan Karangan, 107. Jakarta: Universitas Indonesia, 1994.

Utrecht, E. Pengantar Hukum Administrasi Negara Indonesia. Bandung: FHPM, 1960. 
HALAMAN KOSONG

320 Jurnal Penelitian Hukum De Jure Vol. 21 No. 3, September 2021: 311-320 